\title{
Analisis Rancangan Peraturan Perundang-undangan \\ Mengeluarkan Aturan tentang \\ Tindak Pidana Lingkungan Hidup dari Rancangan Kitab \\ Undang-Undang Hukum Pidana
}

\section{Muhnur Satyahaprabu dan Raynaldo Sembiring ${ }^{1}$}

Rancangan Kitab Undang-Undang Hukum Pidana (RKUHP) saat ini sedang dibahas oleh panitia kerja (Panja) komisi III DPR RI. Rencana revisi KUHP yang sudah lebih dari 30 tahun digagas akhirnya mulai menunjukan perkembangannya. Salah satu materi baru dalam RKUHP adalah materi mengenai tindak pidana lingkungan hidup yang diatur dalam Buku II pada Bab VIII, mulai Pasal 389 sampai Pasal 390. Sekilas terlihat bahwa RKUHP telah mengalami perubahan dengan mengakomodir aturan tentang tindak pidana lingkungan hidup yang sebelumnya bahkan tidak dikenal dalam KUHP. Hanya saja, perubahan ini tidak menjawab permasalahan lingkungan hidup yang saat ini terjadi.

Masuknya tindak pidana lingkungan hidup dalam RKUHP tentunya tidak lepas dari beberapa kritik. Pertama, aturan tentang tindak pidana lingkungan hidup dalam RKUHP akan sulit untuk diimplementaskan, karena aturan tersebut juga telah diatur secara khusus dalam Undang-Undang Nomor 32 Tahun 2009 tentang Perlindungan dan Pengelolaan Lingkungan Hidup (UU 32/2009). Kedua, pengaturan aturan tentang tindak pidana lingkungan hidup yang hanya berdiri sendiri, mengabaikan fakta yang saat ini eksis bahwa kejahatan lingkungan hidup sangatlah terkait dengan kejahatan di bidang sumber daya alam (SDA) seperti kehutanan, pertambangan, perkebunan, perikanan, kelautan, keanekaragaman hayati, dsb. Kedua poin di atas menjadi kritik utama bagi pengaturan norma tindak pidana lingkungan hidup dalam RKUHP yang akan dibahas dalam tulisan ini.

1 Muhnur Satyahaprabu, S.H. adalah Manajer Kebijakan dan Pembelaan Hukum Wahana. Lingkungan Hidup Indonesia (WALHI). Raynaldo Sembiring, S.H. adalah Peneliti dan Deputi Program Indonesian Center for Environmental Law (ICEL). 


\section{Sulitnya Mengatur Tindak Pidana Lingkungan Hidup}

Dalam perancangan awalnya, RKUHP memiliki semangat dengan menganut mazhab kodifikasi tertutup. Hal ini berarti seluruh aturan tentang tindak pidana seperti tindak pidana korupsi, tindak pidana lingkungan hidup, tindak pidana narkotika dan sebagainya akan diatur dalam KUHP yang baru. Khusus untuk tindak pidana lingkungan hidup, tentunya akan timbul pertanyaan mengenai bagaimana eksistensi aturan tindak pidana dalam UU 32/2009?

Jika mengacu kepada Pasal 63 ayat (2) KUHP, disebutkan bahwa "Jika suatu perbuatan masuk dalam suatu aturan pidana yang umum, diatur pula dalam aturan pidana yang khusus, maka hanya yang khusus itulah yang diterapkan." Ketentuan ini juga diatur kembali dalam Pasal 144 ayat (2) RKUHP yang saat ini dibahas oleh panja yang berbunyi: "Jika suatu perbuatan diatur dalam aturan pidana umum dan aturan pidana khusus maka hanya dikenakan aturan pidana khusus."

Asas yang dimaksud dalam ketentuan di atas dikenal dengan lex specialis derogat legi generalis, yang berarti aturan hukum yang lebih khusus mengenyampingkan aturan hukum yang lebih umum. Seandainya RKUHP disahkan dengan tetap adanya aturan tentang tindak pidana lingkungan hidup, maka tindak pidana lingkungan dalam UU 32/2009 mengenyampingkan aturan tentang tindak pidana lingkungan hidup dalam KUHP. Jika sudah dapat diprediksi bahwa aturan tindak pidana dalam UU 32/2009 yang akan digunakan, apa yang menjadi urgensi RKUHP mengatur tentang tindak pidana lingkungan hidup?

Selain itu, aturan tentang tindak pidana lingkungan dalam RKUHP saat ini hanya mengatur sebagian kecil aturan tentang tindak pidana dalam UU 32/2009. Hal ini dapat dipahami karena UU 32/2009 memiliki karakteristik delik yang khas. UU 32/2009 tidak hanya mengenal jenis delik materiil dan formil saja, tetapi juga ada jenis delik lainnya yang diatur pada Pasal 111, Pasal 113, Pasal 114, dan Pasal 115. Kekhasan ini membuat sulitnya untuk dilakukannya kodifikasi tertutup untuk tindak pidana lingkungan hidup.

\section{Urgensi Untuk Mengeluarkan Aturan Tentang Tindak Pidana Lingkungan Hidup}

Seperti yang telah disebutkan sebelumnya, tindak pidana lingkungan hidup bukanlah merupakan tindak pidana yang berdiri sendiri, dimensi kejahatan 
lingkungan sangat erat kaitannya dengan kejahatan sumberdaya alam. Hal ini tercermin dari inisiatif pemerintah SBY terdahulu yang memperkenalkan pendekatan multi-door dalam penegakan hukum di bidang Sumber Daya Alam dan Lingkungan Hidup (SDA-LH). Pendekatan multi-door tersebut telah dinternalisasi kepada beberapa instiutsi melalui penandatanganan Memorandum of Understanding (MoU) 6 (enam) Kementerian/Lembaga.. Pendekatan multi-door merupakan pendekatan penegakan hukum atas rangkaian/gabungan tindak pidana dengan menggunakan undang-undang terkait di bidang SDA-LH dan undang-undang lainnya seperti undang-undang tipikor, undang-undang pajak, dsb.

Pernyataan di atas mengandung arti bahwa RKUHP seharusnya juga mengakomodir aturan tindak pidana SDA lainnya. Namun hal ini akan menjadi permasalahan tersendiri, karena sulitnya mengategorisasikan delik-delik yang ada pada UU 32/2009 dan undang-undang SDA lainnya. Merujuk pada suatu kajian Indonesian Centre for Environmental Law (ICEL) yang belum dipublikasikan, dari 6 (enam) undang-undang di bidang SDA-LH (Lingkungan Hidup, Perkebunan, Kehutanan, Pencegahan dan Pemberantasan Perusakan Hutan, Kelautan, Konservasi Sumber Daya Alam Hayati dan Pertambangan) didapatkan temuan bahwa sangat sulit untuk dilakukannya kodifikasi tertutup, karena banyaknya kategori jenis delik formil dalam keenam undang-undang tersebut. Selain itu, terdapat juga beberapa konflik aturan antara undang-undang tersebut. Konflik aturan ini kerap menimbulkan ketidakpastian dalam penegakan hukum. Hal ini tentunya merupakan kekacauan sendiri yang seharusnya diselesaikan terlebih dahulu sebelum dikodifikasi ke dalam RKUHP.

Permasalahan berikutnya yang cukup filosofis terkait dengan aturan tentang tindak pidana lingkungan hidup dalam RKUHP, yaitu RKUHP belum mengatur lingkungan hidup sebagai subjek hukum yang harus dilindungi. Sebagaimana diketahui, dalam penegakan hukum lingkungan telah lama dikedepankan posisi lingkungan hidup sebagai subjek hukum yang memiliki hak untuk dilindungi. Salah satu dasar pendukung atas argumentasi ini dapat dilihat bahwa jenis sanksi pidana dalam RKUHP belum mengatur jenis sanksi yang khas dalam tindak pidana lingkungan yaitu jenis sanksi pemulihan fungsi lingkungan. 


\section{Penutup}

Langkah pemerintah dan DPR yang saat ini membahas RKUHP patut didukung sebagai upaya melakukan pembaharuan hukum pidana di Indonesia. Namun, khusus untuk aturan tentang tindak pidana lingkungan hidup sebaiknya dikeluarkan dari RKUHP. Catatan-catatan yang telah disampaikan menjadi salah satu saran agar RKUHP menganut mazhab kodifikasi terbuka seperti kondisi yang terjadi saat ini. 